\title{
INFORMATION MANAGEMENT SYSTEMS FOR MONITORING AND DOCUMENTING WORLD HERITAGE - THE SILK ROADS CHRIS
}

\author{
O. Vileikis ${ }^{\mathrm{a}}{ }^{*}, E$. Serruys ${ }^{\mathrm{b}}$, B. Dumont ${ }^{\mathrm{c}}$, K. Van Balen ${ }^{\mathrm{a}}$, M. Santana Quintero ${ }^{\mathrm{d}}$, P. De Maeyer ${ }^{\mathrm{b}}$, V.Tigny $^{\mathrm{c}}$ \\ ${ }^{\text {a }}$ Raymond Lemaire International Centre for Conservation (RLICC), Katholieke Universiteit Leuven (K.U.Leuven), \\ Kasteelpark Arenberg 1 - B 2431, 3001 Heverlee, Belgium. \\ ona.vileikis@asro.kuleuven.be \\ ${ }^{\mathrm{b}}$ Ghent University, Department of Geography, Krijgslaan 281, S8 B-9000 Gent, Belgium \\ ${ }^{\mathrm{c}}$ GIM nv, Researchpark Haasrode 1505, Interleuvenlaan 5, 3001 Heverlee, Belgium. \\ ${ }^{\mathrm{d}}$ Carleton University, Department of Civil and Environmental Engineering, 1028 Colonel By drive, Ottawa, Canada
}

KEY WORDS: Digital Documentation, Information Management Systems, Monitoring, World Heritage, Silk Roads

\begin{abstract}
:
This paper discusses the application of Information Management Systems (IMS) for documenting and monitoring World Heritage $(\mathrm{WH})$ properties. The application of IMS in WH can support all stakeholders involved in conservation, and management of cultural heritage by more easily inventorying, mining and exchanging information from multiple sources based on international standards. Moreover, IMS could assist in detecting damages and preparing management strategies to mitigate risks, and slowing down the deterioration of the integrity of WH properties. The case study of the Silk Roads Cultural Heritage Resource Information System (CHRIS), a Belgian Federal Science Policy Office funded project, illustrates the capabilities of IMS in the context of the nomination of the Central Asian Silk Roads on the WH List. This multi-lingual, web-based IMS will act as a collaborative platform allowing for the completion of improved transnational nomination dossiers and subsequent monitoring activities with all necessary baseline information to easily verify consistency and quality of the proposal. The Silk Roads CHRIS Geospatial Content Management System uses open source technologies and allows to georeference data from different scales and sources including data from field recording methods and combine it with historical and heritage features documented through various means such as textual descriptions, documents, photographs, 3D models or videos. Moreover, tailored maps can also be generated by overlaying a selection of available layers and then be exported to support the nomination dossier. Finally, by using this innovative information and decision support system, the State Parties and other interested stakeholders will have access to a complete nomination dossier and could therefore respond more effectively to hazards and disaster phenomena.
\end{abstract}

\section{INTRODUCTION}

In the context of an increase in World Heritage (WH) nominations and wide-spread risks to cultural heritage, the application of Information Management Systems (IMS) provide a solution to assist State Parties, site managers and other stakeholders involved in conservation, management, and monitoring of cultural heritage by more easily inventorying, mining, sharing and exchanging information from multiple sources based on international standards. Moreover, IMS aid in the prevention and detection of damages as well as in the preparation of management strategies to mitigate risks, and decelerate the deterioration of the integrity of WH properties.

As depicted in Figure 1, the number of inscribed WH properties is increasing every year. For instance, in the last decade, from 2000 to 2011, 246 new properties were inscribed on the List. Up to date, a total of 725 cultural, 183 natural and 28 mixed WH properties exist. However, these figures do not show the actual number of sites or monuments protected by the 1972 World Heritage Convention. Different types of nominations such as e.g. heritage routes include several component parts inscribed as one property. For example, in 2010 the cultural route Camino Real de Tierra Adentro in Mexico was inscribed under one property containing 60 component parts connected by the Royal Inland Road. Other examples of serial inscriptions are the Australian Convicts Sites in 2010 with 11 component parts, or the Prehistoric Pile Dwellings around the Alps in 2011

\footnotetext{
Corresponding author.
}

including 111 stilt houses located within six State Parties. Similar to these, other serial transnational nominations are being prepared such as the Qhapaq Nan in South America, the Viking Age Monuments and Sites, or the Silk Roads. This paper will focus on the latter one.

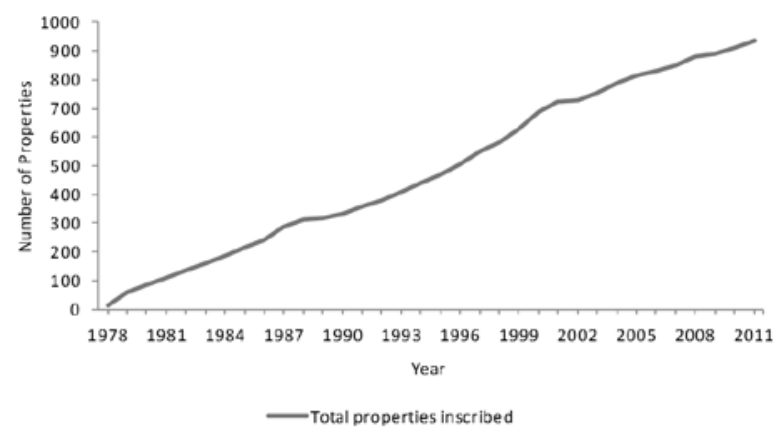

Figure 1: Cumulative of total properties inscribed on the World Heritage List. Data source: UNESCO World Heritage Centre (WHC), http://whc.unesco.org/en/list

After more than seven years of workshops and meetings among the State Parties involved in the Silk Roads WH nomination, initially, in Central Asia the Republics of Kazakhstan, Tajikistan and Uzbekistan, the Kyrgyz Republic and Turkmenistan, and the People's Republic of China, the representatives of the 12 State Parties agreed during the Ashgabat meeting in 2010 on adopting the concept of corridors 
as part of the nomination strategy. Corridors are route segments capturing a variety of paths and roads as well as types of unique heritage sites along the Silk Roads, 54 main corridors were identified from which two along Central Asia and China will be nominated in a first phase (Williams 2012). This concept was proposed by the ICOMOS Silk Roads Thematic Study based on the outcomes of the Ittingen meeting, where the possibility of "nominating a series of single properties under a common framework (but not constituting a single property)" was discussed (Swiss Federal Office of Culture et al. 2010, pp.7071 ), to find a more sustainable way to carry out nominations and manage the sites after their inscription.

Nominations like the Silk Roads, including more than several dozens of sites, require not just good coordination among the State Parties involved but also appropriate tools and methodologies to properly document the sites. Among the Central Asian countries, the Monument Passport System was identified as the common inventory system. However, the information included is often insufficient for the WH nomination or not digitized (Williams 2012). Here, technical support is required. One exception is the example of Kazakhstan where passport forms are digital and improved according to international standards, and the recording methodology of heritage sites could be used as a best practice in other parts of the region. In response to this need, since 2010, the Belgian Federal Science Policy Office (BELSPO) is funding together with the support of the WHC, and in collaboration with the State Parties involved in the nomination, a three-year project: the Silk Roads Cultural Heritage Resource Information System (CHRIS). It aims to assist the documentation and preparation of the serial transnational Silk Roads WH nominations as well as their later management and monitoring with the development and implementation of a Geospatial Content Management System (GeoCMS).

\section{DOCUMENTATION WITH GEOSPATIAL CONTENT MANAGEMENT SYSTEM}

Documentation is the first step to understand the heritage sites and their context. This is achieved by gathering adequate baseline information on values, stakeholders, physical condition and management practices (Demas 2002), data that could be recorded, structured and shared in an easier manner with the use of IMS.

The physical conditions of the site or monument as well as the threats and causes of deterioration could be recorded by different surveying techniques from direct hand measurements to advanced digital technology such as laser scanners or remote sensing tools, depending on the complexity and scale of the site (Bryan et al. 2009). This variety of tools produces different types of data that later are integrated in a single system. In case of serial transnational nominations, this task is more complex as a large volume of data has to be handled. Metadata and data standardization are also essential, as information needs to be shared among several stakeholders. The geographical location of the sites plays a crucial role to better understand the context, gather additional information about the sites or perform comparative or advanced analysis on them such as identifying the trend of threats affecting the properties. To support the latter task, Geographic Information Systems (GIS) and Remote Sensing proved to be valuable tools (Hernandez 2002).

\subsection{GIS and Remote Sensing as tools for documentation and detecting changes}

GIS and Remote Sensing are tools increasingly often used in conservation of cultural and natural heritage. GIS has emerged as a mean to manage and analyse information more efficiently and effectively (DiBiase et al. 2006). This tool not only answers questions such as "what" or "when" but specifically the "where" question by creating relationships between the data and the spatial information recorded in a database (Longley et al. 2011). GIS includes spatially, non-spatially and temporally related features. In the example of cultural heritage, spatial features provide always a location showing e.g. how close the sites are related to other objects or which sites are within certain boundaries; non-spatially related information show for example the gender of the person buried and temporally related to e.g. time dates. These attributes brought together in a GIS environment have the capability to keep track of all the data acquired, classify it in different types, and allow its spatial visualization and analysis.

GIS has a variety of applications in cultural heritage. It is mainly used in field work to record data of excavations, in modelling to create surface models to locate archaeological remains, in resource and data management or land use archaeology to prepare data for future field survey.

Some common GIS applications for cultural heritage are spatial queries, thematic maps, or management of remote sensing data. First, spatial queries display the spatial information rapidly enough to find additional information on e.g. topological connections or relationship between objects, distribution of survey data to visualize site development in the past or in tourism management, by performing complex analyses that allow for customized maps, charts and statistics, e.g. superimposing layers. Second, thematic maps developed out of the data illustrate e.g. the distribution of objects or sites within an area (Longley et al. 2011). Finally, remote sensing technologies include the use of (1) satellite images, (2) prospection and (3) digitization.

(1) Satellite images are commonly used to identify new sites and delimit boundaries (composite satellite images) or changes (multi-temporal images) as shown in the examples below. Aminzadeh and Samani (2006) implemented the use of composite satellite images to delineate the ancient boundaries of Persepolis in Iran. A combination of Landsat ETM+, black and white aerial images and topographic maps, was used to detect archaeological features and remains of possible guard walls and watchtowers. Barlindhaug et al. (2007) applied the multi-temporal images method to detect natural re-growth processes and to identify archaeological sites threatened by these processes. This study used the bands of Landsat images of three archaeological sites in Norway to calculate the Normalized Difference Vegetation Index (NDVI) used to differentiate vegetation from other types of land use. For visualization purposes, including temporal changes, Google Maps satellite view offered as background layer could be an affordable solution. For example, it is possible to view images from several acquisition dates by using the timeline application, with which temporal changes can be visualized, such as the shrinkage of the Aral Sea. (2) Prospection is a non-destructive method useful e.g. in archaeology to discover new sites or to identify the full extent of the site and define and map the relevant areas, without actually disturbing the site. Common remote sensing prospection techniques are aircraft-mounted 
geophysical methods such as geo-electrics, radar or electromagnetics. Lastly, (3) Digitization of maps or sites on the GIS platform in vector format is useful, for example to easily calculate the area of a site or link it to its specific attributes.

Different authors (Box 1999; Hernandez 2002) promote the use of GIS in cultural heritage and see their further application in site monitoring, as is proposed by the European Space Agency and UNESCO 'Open Initiative on the use of space technologies to support the World Heritage Convention'. Others (Boccardi 2002) are more sceptical about its use, especially in developing countries. No matter the differences of opinions, GIS is becoming a powerful management tool together with improved management databases, serving as another type of communication where information and knowledge can be easily shared (Meyer et al. 2007).

\subsection{Geospatial Content Management Systems (GeoCMS) in Cultural Heritage}

The need for documenting, standardizing and visualizing information in a user-friendly way, together with the advantages of GIS, GeoCMS, an advanced form of IMS, are becoming more popular in the field of cultural heritage. A GeoCMS is a software tool used to manage, search and publish various kinds of digital media and electronic text, implemented as a web application and hence allowing for the creation and management of HTML content. It manages and controls a large, dynamic collections of web material (HTML documents and their associated images) providing an additional functionality to a geoportal for managing as well as viewing geographic information over the internet. For the system administrator it provides tools for uploading geographic information and deploying geographic web services so as the website visitor can view geographical information, navigate and perform basic spatial analysis. Examples of current practices of IMS in cultural heritage are listed in Table 1 . Most of the systems are openly accessible to the public but require additional registration to edit data. However, there is currently no open system supporting the preparation of WH nominations.

\begin{tabular}{|c|c|c|c|}
\hline Name & Objective & Accessibility & Link \\
\hline $\begin{array}{l}\text { UNESCO World } \\
\text { Heritage Centre }\end{array}$ & $\begin{array}{l}\text { Archive showing the } \\
\text { properties included in } \\
\text { World Heritage List and } \\
\text { their related activities }\end{array}$ & shared public & hiltp //whic unesco org \\
\hline $\begin{array}{l}\text { Middle Eastern } \\
\text { Geodatabase for } \\
\text { Antiquities (MEGA } \\
\text { Jordan) }\end{array}$ & $\begin{array}{l}\text { Database of } \\
\text { archaeological sites in } \\
\text { Jordan }\end{array}$ & $\begin{array}{l}\text { Restricted } \\
\text { access }\end{array}$ & http///megajordan org \\
\hline $\begin{array}{l}\text { Global Heritage } \\
\text { Network (GHN) }\end{array}$ & $\begin{array}{l}\text { An Early Warning and } \\
\text { Collaborative Solutions } \\
\text { Platform }\end{array}$ & $\begin{array}{l}\text { Open access } \\
\text { and restricted } \\
\text { community } \\
\text { access }\end{array}$ & $\begin{array}{l}\text { hitp/lahn. qlobalherita } \\
\text { gefund org/explore ph } \\
\text { R }\end{array}$ \\
\hline Berlin Wall & $\begin{array}{l}\text { Interective } \\
\text { documenting the Berlin } \\
\text { Wall }\end{array}$ & shared public & $\begin{array}{l}\mathrm{http} / / \text { wuw denkmallar } \\
\text { dschaft-berliner- } \\
\text { maver.de }\end{array}$ \\
\hline $\begin{array}{l}\text { Heritech for the city of } \\
\text { Biograd na Moru }\end{array}$ & $\begin{array}{l}\text { GeolCT for the } \\
\text { preservation and } \\
\text { promotion of Croatian } \\
\text { Cultural Heritage }\end{array}$ & shared public & $\begin{array}{l}\text { http://unww. biograd- } \\
\text { heritech hr }\end{array}$ \\
\hline $\begin{array}{l}\text { Monument Watch } \\
\text { Flanders }\end{array}$ & $\begin{array}{l}\text { Monitoring and } \\
\text { maintenance system for } \\
\text { the Built Cultural Heritage } \\
\text { in the Flemish Region, } \\
\text { Belgium }\end{array}$ & shared public & $\begin{array}{l}\text { http: //nnw monument } \\
\text { enwacht.be }\end{array}$ \\
\hline
\end{tabular}

Table 1: Information Management Systems in Cultural Heritage

\section{WHAT IS THE SILK ROADS CHRIS?}

The Silk Roads CHRIS is a bespoke GeoCMS that has been tailored to support the preparation of the serial transnational Silk Roads nomination dossier based on the Operational Guidelines (UNESCO 2011 Annex 5) and serves as first baseline information for future monitoring and reporting after the inscription of the sites on the WH List. The structure of the system was defined based on the outcomes of meetings held with the Central Asian State Parties working on the Silk Roads WH nomination and in consultation with international experts and the UNESCO WHC. User requirements for this system were: (1) easy to use, (2) web-based, allowing exchange of information at a transnational level, (3) multilingual, (4) based on the corridors concept, (5) able to standardize data types, (6) interoperable by importing data from and exporting data to other software applications e.g. the nomination dossier, maps or other information such as the ICOMOS Silk Roads thematic study and expendable to later include other nominations of the Silk Roads outside Central Asia, (7) able to track the history during the process of nomination and for future monitoring, (8) and featuring a user rights management.

The Silk Roads CHRIS contains three major components: a GeoCMS with a configurator, a geospatial database and a geographic data server. The GeoCMS has been built using recent J2EE technologies and Java standards: Java Server Faces, the Seam application framework, the Rich Faces JSF toolkit, JSR286 portlets, JPA, and JAXB. It is fully configured towards the elaboration of the nomination dossiers for the Silk Roads. Specific data models for corridors as well as for their component parts have been developed. Every corridor has its own settings handled in the GeoCMS configurator. These settings include maps with data layers, group layers, legends, scale dependency, zoom level, search entries, and number of returned columns. All configured information is stored by the GeoCMS in the geospatial database and serviced via a geographic data server.

The geospatial database (PostGreSQL/PostGIS) is a centralized database, containing geographical information, but also the configuration information of the GeoCMS. The open source PostGreSQL database is employed; it includes a PostGIS extension that provides geospatial capabilities to store geographic objects within a spatially enabled CMS. Its architecture is recognised for its stability and performance. In combination with PostGreSQL/PostGIS, the open source GeoServer product is used. GeoServer is an advanced open source Geographic Web Service employed to provide geographic vector and raster data sets via the OGC Web Map Service and Web Feature Service protocols. One of the strong points of GeoServer is its easy-to-use web-based configuration tool. With GeoServer there is no need to bother with long complicated configuration files.

\subsection{Key functionalities}

The Silk Roads CHRIS is a "user friendly" platform considering that a number of end-users do not have an in-depth experience and expertise in computer science, ICT and GIS. It does not require any browser plug-in or applets. The State Parties are guided through the online nomination dossier and its sections. The whole system is multilingual, for now, in English and Russian. New languages can easily be added as all software commands, e.g. load, save, as well as tools, tooltips, menus, and fields are grouped in a message bundle or data model that can then be translated in batch. The system is open and interoperable, based on Open Standards for data models and formats including metadata, and spatial web services. The use of standards facilitates data exchange, querying and allows for efficient reuse of data in a variety of other applications. 
Different counters: The Silk Roads CHRIS is fully configurable. For this project, three spatial scales were defined (1) a global scale with an overview of the whole Silk Roads network (2) a regional scale with the corridors and (3) a local scale where the nominated area and buffer zones of the sites are visualized. Different counters give thus access to these levels of information and associated tools, e.g. editing, as a function of the corridor and user profile configured with a specific menu. Due to the interoperable character of the system, more corridors and sites can be added at any time. To show the capabilities of the system, these counters were populated with data collected from the State Parties on sites that are already on the WH List, and the data gathered by the ICOMOS Silk Roads Thematic Study (Williams \& Wordsworth 2010). This data was first prepared to create the different layers and the corresponding symbology (Styled Layer Descriptors). These layers were then uploaded to the system and GeoServer was used to configure the web services giving access to these layers via the GeoCMS.

Background Maps: The Google Maps API was used to implement satellite and map background layers in the Silk Roads CHRIS demonstrator provide rich and updated contextual information of relevance to the stakeholders as illustrated in Figure 2. The advantage of Google Maps is that its service offers good performance and is stable as well as usually available. High-resolution images can be freely consulted via Google Maps satellite view, which provides high-resolution recent satellite and aerial images all over the world. The main disadvantages of Google Maps are that Google reserves the right to include advertising in the map images provided through the service and that they can limit the number of requests. In addition, Google Maps operates with the Mercator projection system, which implies that all datasets with WGS84 coordinates must be reprojected, a task done by GeoServer.

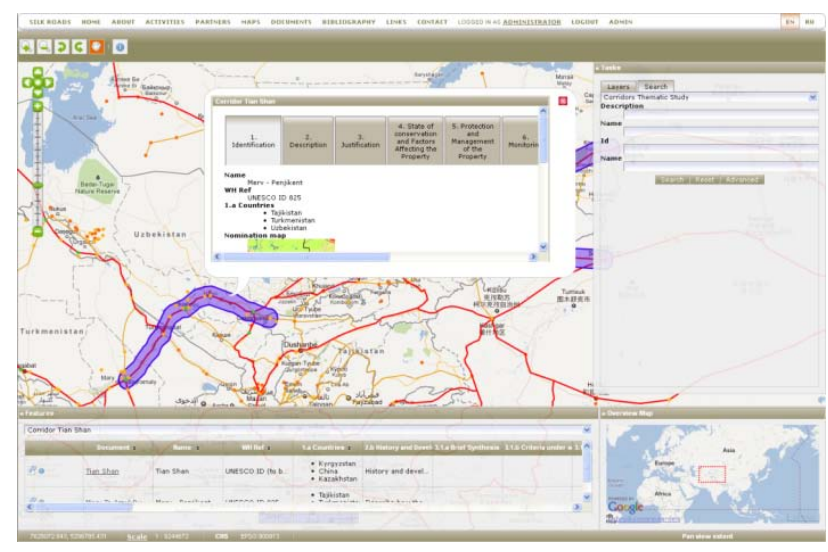

Figure 2: Corridor map (c) Silk Roads CHRIS.

Nomination dossier for corridors and component parts: An editable nomination dossier including all the information required by the Operational Guidelines (Annex 5) (UNESCO 2011) was also designed and implemented. It contains not only the information available for a given corridor to be nominated on the WH List but also its geographical information as well as linked counters and component parts (Figure 3). Different kinds of data can be added to the GeoCMS, from texts to photos to advanced 3D models. The more accurate the information, the easier it will be for the State Parties later on to both monitor and report the changes in time, and make informed decisions.

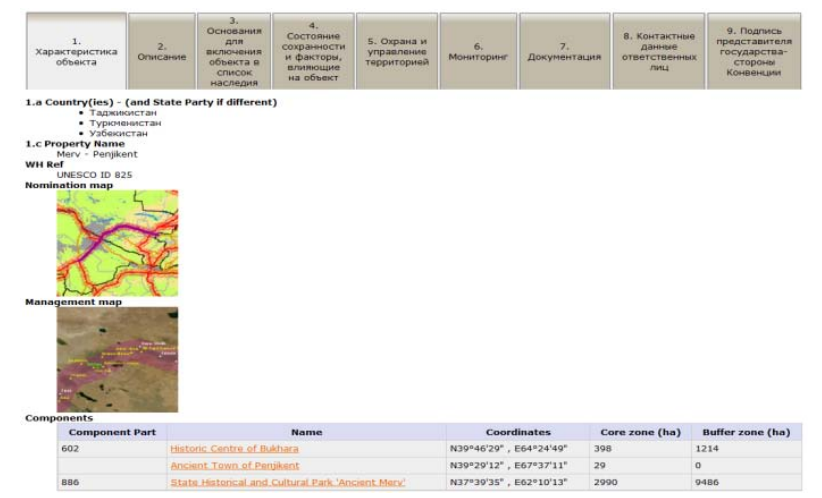

Figure 3: Nomination Dossier (C) Silk Roads CHRIS.

Vector Data in the Silk Roads CHRIS: The GeoCMS allows for creating or modifying the delineation of the nominated area and buffer zone for each component part. By opening the component part model in edit mode, the user will be able to draw and reshape with simple clicks the boundaries based on the Google Maps background data (See Figure 4).

Based on this geometry, the area of the nominated area and buffer zones is calculated by using the getArea function from the Geometry Class of the Java Topology Suite (JTS). This area for each component part belonging to a corridor is automatically displayed in the corridor data model table. Also, the coordinates of the centre point of the nominated area are displayed in the table (See Figure 3). These coordinates are calculated using the getCentroid function of the Geometry Class of the JTS.

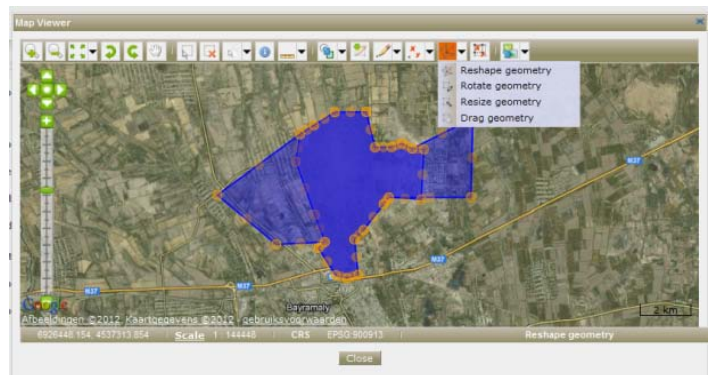

Figure 4: Example of Component Part @ Silk Roads CHRIS.

Raster data in the Silk Roads CHRIS: To support the nomination and to more accurately locate boundaries and buffer zones as recommended by UNESCO (2010; 2011), other maps and more detailed background information such as satellite images were implemented in the GeoCMS (See Figure 5). The background data is composed of the Aster GDEM (METI and NASA) showing the elevations of the area of interest, the Aquastat (Hoogeveen) and RWD2 database (Dooley) containing the rivers, the Vmap0 data (NIMA) from which the lakes and administrative borders are used, as well as the database of the ICOMOS Silk Roads Thematic Study (Williams \& Wordsworth 2010) from which e.g. the current important cities and the network of routes were derived, and high resolution satellite imagery of Digital Globe (2012), provided by Google maps.

Raster data, such as scanned topographical maps and Landsat imagery, was also added to the GeoCMS. Raster data is first georeferenced by converting the row/column locations to their 
actual real-world coordinates (WGS84). After that, for performance reasons, pyramids were built. Pyramids can speed up the visualization of raster data while loading only the necessary layer out of the pyramid. A low-resolution copy of the data is displayed much faster than a high-resolution dataset.

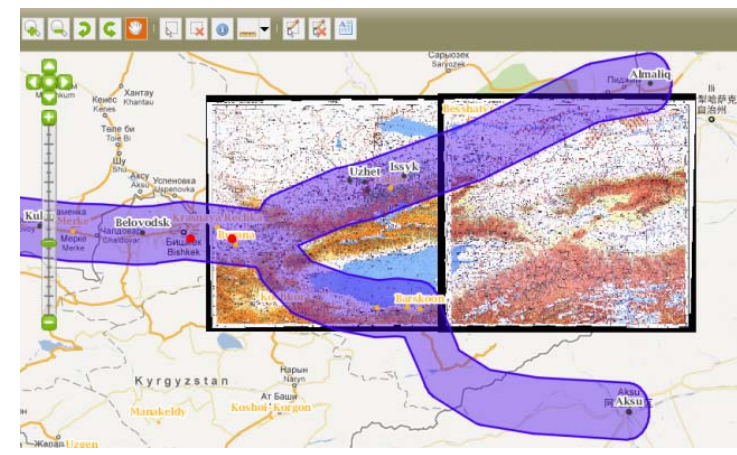

Figure 5: Example of georeferenced scanned topographic maps (C) Silk Roads CHRIS.

Landsat ETM and other satellite images are implemented in the Silk Roads CHRIS. These images are a component of NASA's Earth observation program, which supplies high-resolution visible and infrared imagery from six satellites since 1972. The used sensor here is the ETM+ which has also thermal and panchromatic images available. The data designed to be appropriate for land cover analysis was collected from the Global Land Cover Facility (2010). The images are from 2005 with a spatial resolution of $30 \mathrm{~m}$. Table 2 gives an example of the data collected. Since the data was available in separate bands, a true colour composite was created. Table 3 shows for every band of the sensor, the wavelength they intercept, their spatial resolution and the spectral band. Since the sensors on board of satellites are able to observe several spectral bands, including the parts of the electromagnetic spectrum that are invisible to the human eye, also false colour composites can be generated.

\begin{tabular}{lllll}
\hline ID & Year & Resolution & Coverage & Source \\
\hline p155r33 & 2005 & $30 \mathrm{~m}$ & Tian Shan & $\begin{array}{l}\text { Global land Cover Facility: } \\
\text { GLS2005 }\end{array}$ \\
\hline p155r32 & 2005 & $30 \mathrm{~m}$ & Tian Shan & $\begin{array}{l}\text { Global land Cover Facility: } \\
\text { GLS2005 }\end{array}$ \\
p154r32 & 2005 & $30 \mathrm{~m}$ & $\begin{array}{l}\text { Tian Shan, } \\
\text { Kanka, } \\
\text { Shahruhiya }\end{array}$ & $\begin{array}{l}\text { GLS2005 } \\
\text { GLaner Facility: }\end{array}$ \\
p154r31 & 2005 & $30 \mathrm{~m}$ & $\begin{array}{l}\text { Tian Shan } \\
\text { Global land Cover Facility: } \\
\text { GLS2005 }\end{array}$ \\
p154r30 & 2005 & $30 \mathrm{~m}$ & Tian Shan & $\begin{array}{l}\text { Global land Cover Facility: } \\
\text { GLS2005 }\end{array}$ \\
p153r31 & 2005 & $30 \mathrm{~m}$ & Tian Shan & $\begin{array}{l}\text { Global land Cover Facility: } \\
\text { GLS2005 }\end{array}$
\end{tabular}

Table 2: Example of used Landsat ETM+ imagery.

\begin{tabular}{|c|c|c|c|}
\hline \multicolumn{4}{|c|}{ Enhanced Thematic Mapper Plus (ETM+) } \\
\hline Band & Wavelength $(\mu \mathrm{m})$ & $\begin{array}{l}\text { Resolution } \\
\text { (m) }\end{array}$ & $\begin{array}{c}\text { Spectral } \\
\text { band }\end{array}$ \\
\hline 1 & $0.45-0.52$ & 30 & Blue \\
\hline 2 & $0.52-0.60$ & 30 & Green \\
\hline 3 & $0.63-0.69$ & 30 & Red \\
\hline 4 & $0.77-0.90$ & 30 & Near Infrared \\
\hline 5 & $1.55-1.75$ & 30 & Near Infrared \\
\hline 6 & $10.40-12.50$ & 60 & $\begin{array}{l}\text { Thermal } \\
\text { Infrared }\end{array}$ \\
\hline 7 & $2.09-2.35$ & 30 & Mid Infrared \\
\hline 8 & $.52-.90$ & 15 & Panchromatic \\
\hline
\end{tabular}

Table 3: Bands of the ETM+ sensor. Source: (De Maeyer et al. 2011; United States Geological Land Survey 2010).
In order to obtain a true colour composite the bands of the ETM+ sensor were combined with their true colour on screen. The ArcMap Composite bands tool creates a RGB composite out of individual composite bands (See Table 3). The collected and edited images cover the Tian Shan Corridor. Their spatial resolution $(30 \mathrm{~m})$ allows visualizing up to a scale of 1: 200 000, sufficient to see the global structure of cities and settlements and their environment but insufficient to determine the buffer and nominated areas of the component parts. Therefore, satellite images with higher resolutions are needed such as Ikonos and Quickbird, with 4 and 2.44 meter resolutions (Landsat Imagery 2010) but they are not freely available.

Querying: All source geodata is searchable and configured for any kind of vector data. Data matching the query is presented in a tabular form, sorted and allowing grouping. Through the configurator, the administrator can define the attributes that a user should be able to query upon, e.g. dropdown list boxes, free text searches, datum controls, as well as default values. A bibliography section was especially designed for the Silk Roads CHRIS. It allows the user to search for a bibliography item, upload a new one or download the result list as well as add it to the nomination dossier. All information is stored in the PostgreSQL/PostGIS database.

Tracking and exporting your information: The users can track the information added to the system, comment on the changes and reverse them. This tool will serve to verify and control the nomination process. At the end, based on a checklist, the user will be able to print the nomination dossier to a PDF and export some of the data (See Figure 6). When the user is explicitly interested in geographical vector data, these can be exported to ESRI Shapefile or other formats. The list of export formats can be accessed via the configurator.

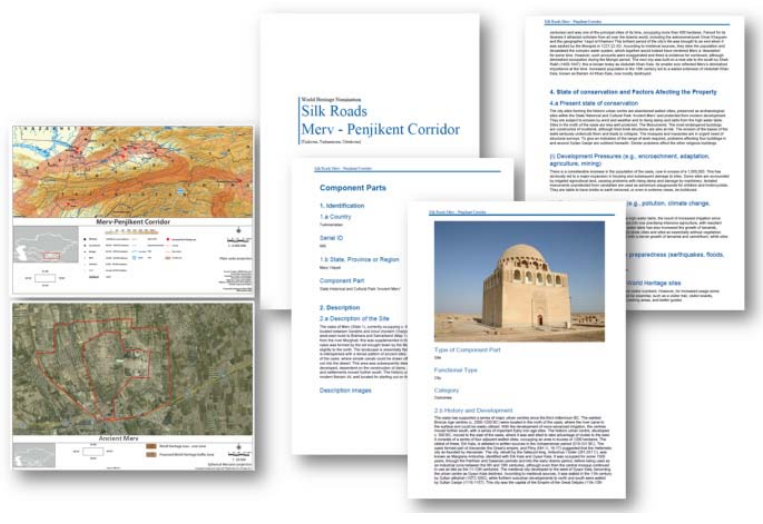

Figure 6: Example of a nomination dossier and maps. (C) Silk Roads CHRIS.

User management and privileges: Various end-users will interact with the system in different ways according to their responsibilities and interest. To that purpose, specific user groups are defined and corresponding privileges are assigned.

Timeline as a tool for monitoring: The GeoCMS also offers an advanced and modern technique to add an additional dimension, time, to a map and its associated information. To that purpose a specific data model containing for each feature one or multiple, start or end dates has to be designed and implemented. Several definitions of these dates can even coexist in the system so as to handle for example the modifications applied to a building since its construction or to 
record conservation or restoration measures. The system user has then the opportunity to navigate across time or to play animations using a dynamic timeline. By simply double clicking or dragging the mouse on the latter the user select a given period and then only the data that is "valid" in that period is displayed.

\section{CONCLUSIONS}

By accurately collecting the baseline information of the sites and by subsequently continuously recording interventions as well as monitoring the State of Conservation and the threats affecting the property, the site values can be more effectively protected.

GeoCMS are changing the way of working in cultural heritage. Before, information was archived on a computer and sharing this information proved often difficult. With the increase in protected sites on the WH List, integration with other inventories is needed; data should be reliable and easy to share, metadata needs to be included. GeoCMS positively replies to these issues. The case study of the Silk Roads CHRIS is a good example how preparation and management of serial transnational World Heritage nominations can be supported by GeoCMS.

Integrating the timeline tool as an additional dimension together with the use of remote sensing and additional features of site monitoring could help to identify the changes of the properties. This tool will be implemented in the Silk Roads CHRIS for the future management of the property.

\section{ACKNOWLEDGEMENTS}

The authors wish to acknowledge the support of BELSPO, the UNESCO WHC and the UNESCO Regional Offices in Almaty and Tashkent. In addition, we would like to thank Prof. Tim Williams, University College London, Archaeology for his constant advice and sharing information to populate the Silk Roads CHRIS. Finally, we would like to thank all State Parties participating in the Silk Roads CHRIS project.

\section{REFERENCES}

Aminzadeh, B. \& Samani, F., 2006. Identifying the boundaries of the historical site of Persepolis using remote sensing. Remote Sensing of Environment, (102), pp.52 - 62.

Barlindhaug, S., Holmolsen, I. \& Tømmervik, H., 2007. Monitoring archaeological sites in a changing landscape using multitemporal satellite remote sensing as an "early warning" method for detecting regrowth processes. Archaeological Prospection, (14), pp.231-244.

Boccardi, G., 2002. Improving Monitoring for World Heritage Conservation. In Monitoring World Heritage. World Heritage Papers 10. UNESCO WHC and ICCROM, pp. 39-41.

Box, P., 1999. GIS and Cultural Resource Management, Bangkok: UNESCO.

Bryan, P., Blake, B. \& Bedford, J., 2009. Metric Survey Specifications for Cultural Heritage, Swindon: English Heritage.
Demas, M., 2002. Planning for Conservation and Management. A values-based approach. In Conservation and Management of Archaeological Sites. International Workshop Organized by the Getty Conservation Institute and Loyola Marymount University. Los Angeles: The Getty Conservation Institute.

DiBiase, D. et al., 2006. Geographic Information Science and Technology Body of Knowledge, Association of American Geographers.

Digital Globe, 2012. Quickbird. Available at: http://www.digitalglobe.com/ [Accessed January 20, 2012].

Dooley, J., RWDB2 Rivers and Surface Water Body Outlines. Available at: http://www.fao.org/geonetwork [Accessed December 20, 2011].

Hernandez, M., 2002. Use of satellite imagery and geographical information systems to monitor world heritage. Monitoring World Heritage, 10, pp.98-109.

Hoogeveen, J., Rivers in the Near East (Derived from HydroSHEDS). Available at: http://www.fao.org/geonetwork [Accessed December 20, 2011].

Landsat Imagery, 2010. Global Land Cover Facility. Available at: http://glcf.umiacs.umd.edu/data/ landsat/ [Accessed March 22, 2012].

Longley, P.A. et al., 2011. Geographic Information Systems and Science Third., John Wiley \& Sons, Inc.

De Maeyer, P., De Wulf, A. \& Van de Weghe, N., 2011. Basisbegrippen geomatica, Gent: Academia Press.

METI and NASA, Release ASTER Global DEM. Available at: http://www.ersdac.or.jp/GDEM/E/4.html [Accessed December 22, 2011].

Meyer, É. et al., 2007. A web information system for the management and the dissemination of Cultural Heritage data. Journal of Cultural Heritage, 8(4), pp.396-411.

NIMA, Vector Map Level 0 (VMAP). Available at: http://earthinfo.nga.mil/publications/vmap0.html [Accessed December 20, 2011].

UNESCO, 2011. Operational Guidelines for the Implementation of the World Heritage Convention. UN Doc WHC. 11/01 November 2011. Available at: http://whc.unesco.org [Accessed January 2, 2012].

UNESCO, 2010. Preparing World Heritage Nominations.

United States Geological Land Survey, 2010. Band designations. Available at: http://eros.usgs.gov/\#/Find_Data/Products_and_Data_Available /band [Accessed March 22, 2012].

Williams, T., 2012. Silk Roads Thematic Study. Interim Report.

Williams, T. \& Wordsworth, P., 2010. Silk Roads Thematic Study. Interim Report. 